\title{
Role of Foliar Application of Some Microelements in Management of Onion Basal Rot
}

\author{
Abd-El-Baky, A.A.; Morsy, S.M.A. and Khalifa, \\ M.M.A. \\ Plant Pathology Research Institute, Agricultural Research \\ Center, 12619, Giza, Egypt.
}

\begin{abstract}
The microelements boron, iron and zinc were tested for their effect on the incidence of onion basal rot caused by Fusarium oxysporum f.sp. cepae (FOC) and Fusarium solani (FS). The tested microelements inhibited mycelial growth and spore germination of the causal pathogens and their counts in the soil and rhizosphere of onion plants. In field experiments, the results of the two seasons indicated that spraying of microelements resulted in significant reduction to the disease during stoage with significant increas to bulbs yield and their diameter. Generally, spraying with the tested microelements at the rate of $50 \mathrm{~g} / 100 \mathrm{~L}$.water was more effective in reducing onion basal rot than $100 \mathrm{~g} / 100 \mathrm{~L}$.water.

The percentages of onion basal rot after five months of bulb storage were determined. In storage experiments, results indicated that boron was the least effective in reducing the disease, which resulted in $19.75 \%$ disease infection, on the average at the rate of 50 g/100L.water. On the other hand, iron treatment was the most effective one in this respect $10.0 \%$, on the average followed by zinc $11.25 \%$, on the average during 2008/2009 and 2009/2010 growing seasons. The activity of the oxidative enzymes, i.e., peroxides and polyphenol-oxidase and phenolic compounds were higher in treated onion plants by the microelements compared with control.
\end{abstract}

Keywords: Onion, Allium cepae, Basal rot, chemical inducers, Fusarium oxysporum, Fusarium solani, peroxidase, phenols, polyphenol-oxidase.

Onion (Allium cepae L.) is a crop of great importance in Egypt for local consumption and exportation. It is liable to attack by several diseases, which cause great losses in the field, during transportation and in storage. Basal rot caused by Fusarium oxysporum f.sp. cepae (FOC) is a serious disease on onion. Several studies have been conducted for controlling this disease chemically (El-Shehaby et al., 1997) and biologically (Abd-El Baky, 2005). On the other hand, several investigators found that microelements had an antibacterial and antifungal properties (Mashaal and El-Zawily, 1984; Ibrahim et al., 1987; El-Gamili et al., 1997; Abd- El Moneem et al., 2005 and El-Shehaby et al., 2009). Mahanshi and Stradhaua, (1988) also reduced downy mildew on muskmelon by foliar spray with copper and zinc. Keel et al. (1989) enhanced biocontrol potentiality of Pseudomonas florescens strain CHAo for controlling tobacco black rot caused by Thielaviopsis basicola by addition of $\mathrm{Fe} \mathrm{CI}_{3}$ to soil. On the other hand, the effect of microelements on some crop diseases and yield was studied by Metwally (1986) and Sadat (2002) compared with the untreated control. 
Hanafi (2004) found that the linear growth of Macrophomina phaseolina, Sclerotium rolfsii and Fusarium moniliforme (the causal of peanut root and pod-rot diseases) was decreased by increasing the concentration of zinc, manganese, and cupper as sulphate. Also, she found that sporulation and sclerotia formation of the tested fungi were decreased by increasing the concentration of all tested microelements from 500 to 1000 ppm.

The aim of this work was to study the effect of boron, iron, and zinc as fungistatic materials on the linear growth and spore germination of basal rot fungi under laboratory conditions. Also, the role of these microelements on management of the disease under field conditions.

\section{Materials and Methods}

Trials were carried out to study the effect of boron, iron, and zinc on Fusarium oxysporum f. sp. cepae (FOC) and F. solani (FS) under laboratory conditions. Also, field trails were carried out at Malawy, Minia Governorate. during 2007-2008 and 2008-2009 seasons for management of the disease. The isolated fungi were purified using single spore technique. The purified fungi were identified depending on their morphological features and the description of Booth (1971).

\section{Laboratory experiments:}

1.1. Effect of different microelements on mycelial growth and spore germination:

Boron (Sodium borate) 24.8\% (Elgomhoria chemical co.), Iron [ferrous sulphate $\left(\mathrm{FeSO}_{4}\right)$ ] and Zinc [zinc sulphate $\left(\mathrm{Zn} \mathrm{SO}_{4}\right)$ ] supplied by Sigma-Aldresh Co. at the concentrations of $125,250,500,750$ and $1000 \mathrm{ppm}$ were evaluated for their effect on mycelial growth and spore germination of the two tested fungi. Each concentration was added to $100 \mathrm{ml}$ PDA before solidification, poured in Petri plates and inoculated at the center with $0.5 \mathrm{~cm}$. in diameter discs of 7days - old cultures of any of the two tested fungi and incubated at $26 \pm 2^{\circ} \mathrm{C}$ for 5 days. Medium free from the microelements was used as control. Three replicates were used for each treatment. Mycelial growth was measured when fungal growth covered the surface of any plate. The number of the germinated spores was counted $48 \mathrm{~h}$. after inoculation. A disc of $0.5 \mathrm{~cm}$ in diameter was transferred into sterilized $100 \mathrm{ml}$ of distilled water in sterilized Jar, then one $\mathrm{ml}$ of 1/100 dilution was distributed on PDA medium, incubated at $26 \pm 2{ }^{\circ} \mathrm{C}$ and then the colonies of each fungus were counted.

\section{2- Field experiments:}

Field trials were conducted at Mallawy Exp. Res. Station (planted on mid of December) during 2008-2009 and 2009-2010 growing seasons to investigate the effect of spraying of the tested three microelements on the natural infection by basal rot under field conditions. The field was divided into plots of $42 \mathrm{~m}^{2}$ (7×6 $\mathrm{m}$ and 9 rows) and planted with Giza 20 onion c.v. transplants (aged 60 days). All agricultural practices were followed at the proper time and rates throughout the growing season. Total count of fungal spores was assessing at the end of the experiment (Johanse et al.,1960). The bulbs were harvested when about more than of $50 \%$ of leaves top were down.

Egypt. J. Phytopathol., Vol. 39, No. 1 (2011) 
Microelements were applied as foliar spray at the rate of 50 and $100 \mathrm{~g} / 100 \mathrm{~L}$. water, 30 and 60 days after planting. The untreated plots served as control. Four replicate plots were used for each treatment. Diameter and weight of 100 bulls sampled from each treatment were recorded.

\section{3- Storage experiment:}

Two hundred bulbs were sampled from each field replicate at harvest and stored for five months in plastic net bags under room temperature. The percentages of rotted bulbs were recorded at the end of storage period. Also, biochemical changes associated with the treatment with the microelements were assessed.

4. Biochemical changes associated with the development of onion bulb after spraying with microelements:

4.1. Determination of enzymes activity.

Leaf samples taken from each treatment were collected 3 days after spraying the microelements. Enzyme activities were determined according to Allam and Hollis (1972).

\subsection{Determination of phenolic compounds.}

Free, conjugated, and total phenols were determined in treated and non-treated onion bulbs with the tested microelements. Phenolic extractions were carried out according to a modified method suggested by Johnson and Schall (1957).

\section{Statistical analysis:}

All experiments were designed in complete randomized blocks. Data were statistically analyzed using "F" test and treatments were compared by L.S.D. values according to Gomez and Gomez (1984).

\section{Results and Discussion}

1- The in vitro effect:

Data shown in Table (1) show that the tested microelements i.e., boron, iron and zinc resulted in significant inhibition to the linear growth of the two tested fungi. This inhibition was more pronounced when iron was used, which both fungi failed at $1000 \mathrm{ppm}$ followed by zinc then boron. The metal element may be bound directly to the protein or chelated by a prophyrin or flavin prosthetic group. Iron, molybdenum or zinc are common components of metalloenzymes (Ross,1975). Also, Hanafi (2004) found that number of sclerotia of Macrophomina phaseolina and S. rolfsii and number of spores of $A$. flavus and $F$. moniliforme increased by increasing concentration from 25 to $50 \mathrm{ppm}$ of $\mathrm{ZnSo}_{4}$ and it returned to decreasing at $100 \mathrm{ppm}$.

On the other hand, increasing the concentrations increased the inhibition degree. Duffy and Defago (1997) found that Fusaric acid (FA) production was completely repressed by zinc sulphate as low as $10 \mu \mathrm{g} / \mathrm{mL}$. Also, they added that one or more of the pathogenicity factors may have been insensitive to be suppressed by zinc or may even have been stimulated by zinc. These results are in according with that obtained by Mahmoud et al. (2009), which found that the highest occurrence of aflatoxigenic fungi and seeds aflatoxin contaminations were increased by increasing zinc sulphate from 100 to $200 \mathrm{ppm}$ in both greenhouse and field trials during 2007 and 2008 growing seasons. 
In fact, all elements could be toxic when used at high concentrations, whereas they considered essential at trace concentrations. Observation indicates that the $125 \mathrm{ppm}$ concentration of iron and /or zinc are likely to encourage spore germination of FOC and FS. These results are in according with that obtained by Hanafi (2004).

Table (1): The in vitro effect of certain boron, iron, and zinc concentrations on linear growth of $F$. oxysporum f.sp. cepae and $F$. solani, 5 days after incubation at $26 \pm 2^{\circ} \mathrm{C}$

\begin{tabular}{|c|c|c|c|c|c|c|}
\hline \multirow{3}{*}{$\begin{array}{l}\text { Concentration } \\
(\mathrm{ppm})\end{array}$} & \multicolumn{6}{|c|}{ Linear growth in $(\mathrm{cm})$ of microelements } \\
\hline & \multicolumn{2}{|c|}{ Sodium borate } & \multicolumn{2}{|c|}{ Ferrous sulphate } & \multicolumn{2}{|c|}{ Zinc sulphate } \\
\hline & FOC* & $\mathrm{FS} * *$ & FOC & FS & FOC & FS \\
\hline 1000 & 5.65 & 5.90 & 0.00 & 0.00 & 5.55 & 4.88 \\
\hline 750 & 6.53 & 5.28 & 1.75 & 1.30 & 4.05 & 3.50 \\
\hline 500 & 7.38 & 4.60 & 1.72 & 1.95 & 3.25 & 3.33 \\
\hline 250 & 8.28 & 9.00 & 2.75 & 2.76 & 3.81 & 3.97 \\
\hline 125 & 9.00 & 9.00 & 6.38 & 5.43 & 6.38 & 8.35 \\
\hline Control & 9.00 & 9.00 & 9.00 & 9.00 & 9.00 & 9.00 \\
\hline L.S.D. (0.05) & 0.46 & 0.33 & 0.31 & 0.10 & 0.32 & 0.27 \\
\hline
\end{tabular}

* FOC $=$ F. oxysporum f.sp. cepae, $* * \mathrm{FS}=$ F. solani

2. Field experiments:

Data presented in Table (2) show clearly that PDA medium amended with zinc sulphate and sodium borate at 125, 250 and 500 ppm significantly reduced spore germination of $F$. oxysporum f.sp. cepae, except at $125 \mathrm{ppm}$ for zinc sulphate. However, an increase was occurred at $750 \mathrm{ppm}$ and then returned to reduce at the high rate $(1000 \mathrm{ppm})$. Ferrous sulphate led to complete inhibition of spore germination at all concentrations used except at $125 \mathrm{ppm}$. Low concentration of element may be benefit to physiology of fungal cells, meanwhile at high concentration the fungal cell receptors occurs with saturation of element and then becomes toxic to the fungus. These results can be explained according to Ross (1975) who reported that a metal may have toxic effect if it impairs growth or metabolism of an organism above a certain concentration.

The count of the spores of the two tested fungi under field conditions are shown in Table (3). In general, treatment with boron, iron and zinc at the two tested rates resulted in high reduction in the total count of both fungi in the soil and the rhizosphere of onion plants compared with control treatment. However, it was noticed that boron at $50 \mathrm{~g} / 100 \mathrm{~L}$. Water resulted in high reduction in the total count of F. solani only compared with high concentration $100 \mathrm{~g} / 100 \mathrm{~L}$. water.

This could be explained by the fact that micro-and microelement amendments have been used commercially on a limited scale to manage certain soil-borne diseases including Fusarium wilt of tomato and other vegetable crops (Engelhard, 1989).

Disease reduction is most often attributed to the improve of nutrition that boosts host defenses or to direct inhibition of the fungal growth and activity. Pathogen suppression may also result indirectly from amendment - mediated modification of

Egypt. J. Phytopathol., Vol. 39, No. 1 (2011) 
chemical and physical properties like soil and rhizosphere $\mathrm{pH}$ (Simon and Sivastithamparam,1989) or from alternation of host root exudates to disfavor pathogenic activity (Huber, 1989). Meanwhile, Mandal and Sinha (1992) reported that zinc and other minerals reduce Fusarium wilt of tomato by inducing host resistance.

Table (2): Effect of boron, iron, and zinc on the number of germinated spores of $F$. oxysporum f. sp. cepae and $F$. solani

\begin{tabular}{|l|c|c|c|c|c|c|}
\hline \multirow{3}{*}{\begin{tabular}{c}
\multirow{2}{*}{$\begin{array}{c}\text { Concentration } \\
(\mathrm{ppm})\end{array}$} \\
\cline { 2 - 7 }
\end{tabular}} & \multicolumn{5}{|c|}{ No. of germinated spores $\left(\times 10^{3}\right)$ of microelement } \\
\cline { 2 - 7 } & Sodium borate & \multicolumn{2}{c|}{ Ferrous sulphate } & \multicolumn{2}{c|}{ Zinc sulphate } \\
\hline 1000 & 4.67 & 0.00 & 0.00 & 0.00 & 11.67 & 0.00 \\
\hline 750 & 14.00 & 0.66 & 0.00 & 0.00 & 31.67 & 0.33 \\
\hline 500 & 12.67 & 0.33 & 0.00 & 0.00 & 23.33 & 0.66 \\
\hline 250 & 11.00 & 0.33 & 0.00 & 0.00 & 17.67 & 0.00 \\
\hline 125 & 18.33 & 0.33 & 70.33 & 3.66 & 64.33 & 4.33 \\
\hline Control & 64.33 & 3.00 & 64.33 & 3.00 & 64.33 & 3.00 \\
\hline L.S.D. (0.05) & 3.35 & 1.02 & 1.57 & 0.48 & 4.48 & 1.45 \\
\hline
\end{tabular}

*FOC $=F$. oxysporum f.sp. cepae, ${ }^{* *} \mathrm{FS}=F$. solani

Table (3): Effect of boron, iron and zinc on fungal spore counts in the soil and the rhizosphere under field conditions.

\begin{tabular}{|c|c|c|c|c|c|c|c|c|c|c|c|c|}
\hline \multirow{4}{*}{$\begin{array}{c}\text { Treatmen } \\
\mathrm{t} \\
(\mathrm{ppm})\end{array}$} & \multicolumn{12}{|c|}{ Count of spores $\left(\times 10^{3}\right)$ of microelements } \\
\hline & \multicolumn{4}{|c|}{ Sodium borate } & \multicolumn{4}{|c|}{ Ferrous sulphate } & \multicolumn{4}{|c|}{ Zinc sulphate } \\
\hline & \multicolumn{2}{|c|}{ FOC* } & \multicolumn{2}{|c|}{ FS** } & \multicolumn{2}{|c|}{ FOC } & \multicolumn{2}{|c|}{ FS } & \multicolumn{2}{|c|}{ FOC } & \multicolumn{2}{|c|}{ FS } \\
\hline & 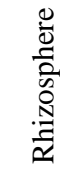 & $\overline{\bar{c}}$ & 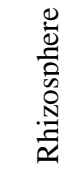 & : & 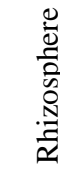 & $\overline{\bar{c}}$ & 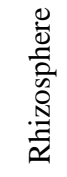 & $\begin{array}{l}\overline{0} \\
n^{2}\end{array}$ & 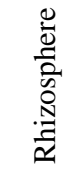 & $\overline{\bar{c}}$ & 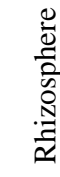 & ī \\
\hline 50 & 113 & 12 & 56 & 6 & 25 & 6 & 25 & 6 & 22.7 & 6 & 0.0 & 0.0 \\
\hline 100 & 300 & 12 & 200 & 7 & 50 & 6 & 50 & 0.0 & 333 & 12 & 83 & 6.1 \\
\hline Control & 333 & 35 & 229 & 24 & 333 & 36 & 229 & 24 & 333 & 36 & 229 & 24 \\
\hline
\end{tabular}

$* \mathrm{FOC}=$ F. oxysporum f.sp. cepae, ${ }^{* *} \mathrm{FS}=$ F. solani

Table (4) shows that the treatments with the tested elements at the rates of 50 and $100 \mathrm{~g} . / 100 \mathrm{~L}$. water resulted in significant reduction to the disease when onion bulbs were storage in a storer during seasons of 2007/2008 and 2008/2009 compared with control treatment. In addition, the low concentration was more efficient in this regard compared with the high concentration.

This may be attributed to fungicidal effect of these microelements when their concentration exceeds a certain limit, Sadat (2002). On the other hand, iron treatment was the most effective followed by zinc. Spraying of onion plants with iron reduced mean of basal rot infection to 10.0 and $12.5 \%$ at 50 and 100 g./ 
100L.water, respectively. Meanwhile, when the plants were sprayed with zinc, the reduction weas 11.0 and $13.75 \%$, respectively. In a few cases, though mineral amendments appear to reduce the disease by stimulating indigenous populations of microorganisms indirectly that are beneficial to plant growth and antagonistic to pathogens (Huber, 1989).

Table (4): Effect of microelements foliar spray on the percentages of basal rot infection in Malawi station during 2008/2009 and 2009/2010 growing seasons.

\begin{tabular}{|c|c|c|c|c|c|c|}
\hline \multirow{3}{*}{ Treatment } & \multicolumn{5}{|c|}{ Percentage of infection at concentrations (ppm) during } \\
\cline { 2 - 3 } & 50 & 100 & \multirow{2}{*}{ Mean } & 50 & 100 & \multirow{2}{*}{ Mean } \\
\cline { 2 - 3 } \cline { 5 - 6 } & $2008 / 2009$ & $2009 / 2010$ & & $2008 / 2009$ & $2009 / 2010$ & \\
\hline Boron & 17.5 & 22.0 & 19.8 & 20.0 & 27.5 & 23.75 \\
\hline Iron & 10.0 & 10.0 & 10.0 & 12.5 & 12.5 & 12.5 \\
\hline Zinc & 12.0 & 10.0 & 11.25 & 15.0 & 12.5 & 13.75 \\
\hline Control & 22.5 & 32.5 & 27.75 & 22.5 & 32.5 & 27.5 \\
\hline L.S.D. at 5\% & 4.9 & 4.9 & ---- & 3.4 & 5.2 & -- \\
\hline
\end{tabular}

Table (5) show clearly that the diameter of onion bulbs treated with elements were greater than that of non-treated ones in the two seasons. However, the weight of onion bulbs treated with elements was higher than the non-treated at the different concentrations.

Onion plant treated with iron at concentration of $50 \mathrm{~g} / 100 \mathrm{~L}$. water gave the highest mean weight $(266.5 \mathrm{~kg})$ followed by the same element $(253 \mathrm{~kg})$ at concentration of $100 \mathrm{~g} / \mathrm{fed}$ of the two successive growing seasons 2007/2008 and $2008 / 2009$. This led to larger bulbs as the absorption of water and nutrients was more efficient (Sadat, 2002).

Table (5). Effect of foliar application with boron, iron and zinc at different concentrations on diameter and weight of onion bulb

\begin{tabular}{|l|c|c|c|c|c|c|c|}
\hline \multirow{2}{*}{ Treatment } & \multirow{2}{*}{$\begin{array}{c}\text { Dose } \\
\text { (ppm) }\end{array}$} & \multicolumn{3}{|c|}{ Weight of Bulbs (Kg) / plot } & \multicolumn{3}{c|}{ *Mean diameter of bulbs in $(\mathrm{cm})$} \\
\cline { 3 - 9 } & $2008 / 09$ & $2009 / 10$ & Mean & $2008 / 09$ & $2009 / 10$ & Mean \\
\hline \multirow{2}{*}{ Boron } & 50 & 257 & 235 & 246.0 & 7.6 & 7.9 & 7.8 \\
& 100 & 232 & 210 & 221.0 & 7.7 & 7.5 & 7.6 \\
\hline \multirow{2}{*}{ Iron } & 50 & 270 & 263 & 266.5 & 8.2 & 8.1 & 8.3 \\
& 100 & 255 & 251 & 253.0 & 7.8 & 8.0 & 8.0 \\
\hline \multirow{2}{*}{ Zinc } & 50 & 260 & 243 & 251.5 & 7.9 & 8.0 & 8.0 \\
\hline \multirow{2}{*}{ Control } & 100 & 250 & 231 & 240.0 & 7.7 & 7.6 & 7.7 \\
\hline \multirow{2}{*}{ Mean } & 50 & 190 & 192 & 195.0 & 7.4 & 7.6 & 7.5 \\
\hline L.S.D. at 5\% & 50 & 245.1 & 233 & ----- & 7.8 & 7.8 & ----- \\
\hline
\end{tabular}

*Values are mean of 100 bulbs for each treatment.

Egypt. J. Phytopathol., Vol. 39, No. 1 (2011) 


\section{Biochemical changes associated with the development of onion bulb after spraying with the} microelements:

\subsection{Determination of enzyme:}

Data presented in Table (6) showed that the different tested systemic resistance inducing agents caused increase in the activates of peroxides and polyphenoloxidase in bulb tissues compared with control.

Zinc caused the highest increase in the activities of peroxides and polyphenoloxidase enzymes at the two doses (50 and $100 \mathrm{~g} / 100 \mathrm{~L}$. water) flowed by iron and boron which showed low activities for the two enzymes. This explains the results obtained that treatment with zinc was the best in decreasing the percentage of infection during storage (Table 4).

Concerning this point, many investigators explained the role of oxidative enzymes on disease. Byrde et al. (1960) indicted that resistance to several plant diseases appeared to be due to inhibition of fungal enzymes by polyphenols and their oxidation products. Badawi et al. (1986) treated onion seedlings with zinc and mixture of it with copper, molybdenum, and manganese. They found that all treatments increased peroxides activity specially zinc + copper + manganese and zinc + copper + molybdenum followed by zinc alone. Meanwhile, zinc alone slightly increased polyphenoloxidase activity. Avdiushko et al. (1993) found that many plant enzymes are involved in defense reaction against plant pathogens.

Table (6): Effect of different concentrations of microelements peroxides and polyphenoloxidase activity (as optical density /g. fresh weight)

\begin{tabular}{|c|c|c|c|c|}
\hline \multirow{2}{*}{ Element } & \multicolumn{4}{|c|}{ Enzymatic activity at two doses (g/100 L. water) } \\
\cline { 2 - 5 } & \multicolumn{3}{|c|}{ Peroxides } & \multicolumn{2}{c|}{ Polyphenoloxidase } \\
\cline { 2 - 5 } & 50 & 100 & 50 & 100 \\
\hline Boron & 4.28 & 2.815 & 0.188 & 0.169 \\
\hline Iron & 4.86 & 3.813 & 0.195 & 0.174 \\
\hline Zinc & 5.43 & 4.44 & 0.41 & 0.311 \\
\hline Control & 4.02 & 4.02 & 0.069 & 0.069 \\
\hline
\end{tabular}

\subsection{Determination of phenolic compound:}

Data tabulated in Table (7) reveal that zinc treatment at $50 \mathrm{~g} / 100 \mathrm{~L}$.water recorded the highest amount of free phenols $(4.28 \mathrm{mg})$, conjugated phenols $(13.6 \mathrm{mg}$.) and total phenols (13.31 mg.), meanwhile, no clear differences were found between boron and ferrous treatments compared to control.

The present data showed that activation of the oxidative enzyme (peroxides and polyphenoloxidase) and phenols was obviously higher in treated onion plants compared to control. These results agree with those recorded by Abdou et al. (2001) and El-Fiki et al. (2004). 
Table (7): Effect of different concentrations of microelements on free, conjugated, and total phenols (mg./g. fresh weight).

\begin{tabular}{|l|c|c|c|c|c|c|}
\hline \multirow{3}{*}{ Element } & \multicolumn{6}{|c|}{ Phenolic compound at two doses (g/100 L. water) } \\
\cline { 2 - 7 } & \multicolumn{2}{|c|}{ Free phenols at } & \multicolumn{2}{c|}{ Conjugated phenols at } & \multicolumn{2}{c|}{ Total phenols at } \\
\cline { 2 - 7 } & 50 & 100 & 50 & 100 & 50 & 100 \\
\hline Boron & 1.92 & 1.41 & 9.31 & 5.65 & 11.23 & 7.06 \\
\hline iron & 2.06 & 1.73 & 9.45 & 6.05 & 11.51 & 7.78 \\
\hline Zinc & 4.28 & 3.85 & 13.6 & 9.46 & 9.32 & 13.31 \\
\hline Control & 1.97 & 1.24 & 10.73 & 6.46 & 8.76 & 7.71 \\
\hline
\end{tabular}

\section{References}

Abd-El-Baky A.A. 2005. Control of some onion rots in North Africa by field and storage treatments. Ph.D. Thesis, African Research and Studies Institute, Cairo Univ., pp 109.

Abd-El-Moneem, K.M.H.; Fawaz, S.B.M.; Saeed F.A. and El-Shehaby, A.I. 2005. Effect of clove size and certain micronutrients on filarial basal rot of garlic. Assiut J. of agric. Sci., 36(4): 163-175.

Abdou, E.; Abd-Alla, H.M. and Galal A.A. 2001. Survey of sesame root rot / with disease in Minia and their possible control by ascorbic and salicylic acids. Assiut J. Agric. Sci., 1:135-152.

Allam, A.I. and Hollis, S.P. 1972. Sulfide inhibition of oxidase in rice root. Phytopathology, 62:634-639.

Avdiushko, S.A.; Ye X.S. and Kuc, J. 1993. Detection of several enzymatic activities in leaf prints of cucumber plants. Physiol. and Mol. Plant Path., 42: 441-454.

Badawi, M.F.M.; Azab, M.W. and Dabash, T.S. 1986. Effect of microelements on incidence of some onion diseases in storage in relation to chemical constituents of bulbs. Agric. Res. Rev., 64(2): 275-284.

Booth, C. 1971. The Genus Fusarium. Commonwealth Mycological institute. Kew, Surrey, England, pp 237.

Byred, R.J.W.; Fellding, A.H. and William, A.H. 1960. The role of oxidized polyphenols in the varietal resistance of apples to brown rot. In: J.B. Pridam (Ed.) Phenolics in Plants in health and disease. Pergamon Press, New York, pp 95-99.

Duffy, B.K. and Defago, G. 1997. Zinc Improves biocontrol of Fusarium crown and root rot of tomato by Pseudomonas fluorescens and represses the production of pathogen metabolites inhibitory to bacterial antibiotic biosynthesis. Phytopathology, 87(12): 1250-1257. 
El-Baz, S.M. 2007. Induction of resistance in some soybean varieties against root rot diseases by some chemicals inducers. Egypt. J. of App. Sci., 22(1):2007.

El-Fiki, A.I.I.; Mohamed, F.G.; El-Deeb, A.A. and Khalifa, M.M.A. 2004. Some applicable methods for Controlling sesame charcoal rot disease (Macrophomina phaseolina) under greenhouse conditions. Egypt. J. Phytopathol., 32(1-2): 87101.

El-Gamili, A.E.; Khalira, E.Z. and Abd El-Hadi, A.H. 1997. The influence of some foliar fertilizers application on seed yield and purple blotch infection of onion (Allium cepae, L.). Menofiya J. Agric. Res., 22(2): 493-507.

El-Shehaby, A.I.; El-Ganieny, R.M.A.; Twadrous, M.I. and Osman, N.A. 1997. Control of post-harvest bulb rots of onion. $8^{\text {th }}$ Congress of Egypt. Phytopathol. Soc, Cairo, 353-363.

El-Shehaby, A.I; Al-Ashaal, M.S. and Tadrous, M.F.I. 2009. Reduction of garlic diseases by micro-element foliar spray. J. Agric. Sci. Mansoura Univ., 34(4): 3837-3842.

Engelhard, A.W. 1989. Soilborne Plant Pathogens: Management of diseases with micro- and macroelements. The American Phyto-pathological Society, St. Paul, $\mathrm{MN}$.

Gomez, K.A. and Gomez, A.A. 1984. Statistical Procedures for Agricultural Research.2 $2^{\text {ed }} 680$ pp. John Wiley Sons, New York. U.S.A.

Hanafi, A.A. 2004. The role of foliar spraying of some microelements on peanut leave spot, root and pod rot diseases incidence and yield. J. Agric. Sci. Mansoura Univ., 29(4): 1727-1736.

Huber, D.M. 1989. The role of nutrition in the take-all disease of wheat and other small grains. Pages 46-74 in Soil borne Plant Pathogens: Management of diseases with micro and macro-elements. A.W. Engelhard, ed. The American Phytopathological Society, St. Paul, MN.

Ibrahim, N.A.; El-Shehaby, A.I.; Radwan, I.A.; Ali, A.A. and Dabash, T.S. 1987. Effect of pre-transplanting fertilization on onion basal rot and soil microorganisms. J. Agric. Sci. Mansoura Univ., 12(1): 20-25.

Johnson, G. and Schaal, L.A. 1957. Accumulation of phenolic substances and ascorbic acid in potato tuber tissue upon injury and their possible role in disease resistance. Amer Potato J., 34: 200-209.

Johansen, L.E.; Curi, E.A.; Bonf, J.H. and Fribourg, H.A. 1960. Method for studying soil microflora-plant disease relationship. Second printing Burge's publishing Co., pp77.

Keel. C.; Voiserd, C.; Berling, C.H.; Kahr, G. and Defago, G. 1989. Iron sufficiency, a prerequisite for the suppression of tobacco black root rot by Pseudomonas fluorescens strain CHAO under gnotobiotic conditions. Phytopathology, 79(5): 584-589. 
Mahnashi, R.P. and Stradhaua, B.S. 1988. Effect of Nutrition on Downey mildew disease caused by Psedoperonospora cubensis. (Berk, Cart). Rostow on muskmelon. Annals of Arid zone, 27(2): 153-155

Mahmoud, E.Y.; Saleh, W.A.M. and Marei, T.A. 2009. Efficiency of microelements as inducer resistance factor of peanut pod rot diseases and aflatoxigenic fungi. Egypt. J. of Appl. Sci., 24 (4A): 91-110.

Mandal, N.C. and Sinha, A.K. 1992. An alternative approach for the chemical control of Fusarium wilt of tomato. Indian Phytopathol., 45: 194-195.

Mashaal. S.F. and El-Zawily A.I. 1984. Effect of foliar nutrition with minor elements on lettuce (Lactuca sativa L.). J. Agric, Res. Tanta Univ. 19(4): 13091316.

Metwally, A.H. 1986. Studies on onion diseases in A.R.E. Ph.D. Thesis, Suze Canal Univ., 165pp.

Morsy, K.M.M. 2005. Induced resistance against damping-off, root rot and wilt diseases of Lentil. Egypt J. Phytopathol., 33(2): 53-63.

Ross, I.S. 1975. Some effects of heavy metals on fungal cells. Trans. Bra. Mycol. Soc., 64(2): 175-193.

Sadat, M.M. 2002. Studies on basal rot disease of onion in Egypt. M.Sc. Thesis, Fac. Agric, Mansoura Univ. 79 pp.

Sharvelle, E.G. 1961. The nature and uses of modern fungicides Burgess Publishing Co. Town \& State, pp.201-213.

Simon, A. and Sivastithamparam, K. 1989. Pathogen-suppression: A case study in biological suppression of Gaeitmannomyces graminis var. tritici in soil. Soil Biology and Biochemistry, 21: 331- 337.

Corresponding author: Abd-El-Baky, A.A.

E-mail: ahmad_abdelbaky2000@yahoo.com 


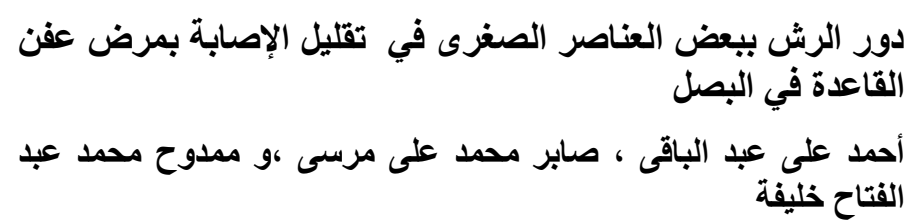

معهد بحوث أمراض النباتات ، مركز البحوث الزراعية ، الجيزة ، مصر

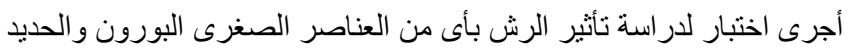

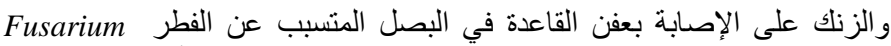
كيث أوضحت النتائج oxysporum f.sp. cepae and Fusarium solani المعملية أن لهذه العناصر القدرة على تثبيط نمو ميسليوم و إنبات جر اثثم الفطرين.

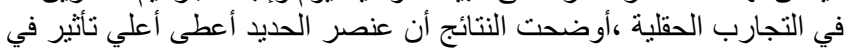

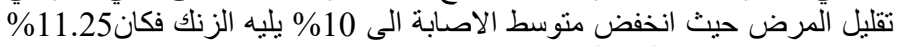

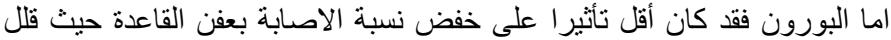

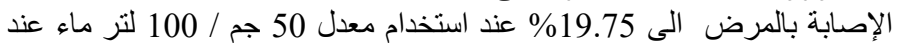
نفس المعدل السابق خلال موسمى النمو 2008/2007 و و2009/2008 مقارنة

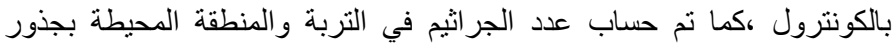

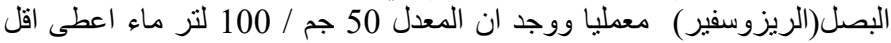

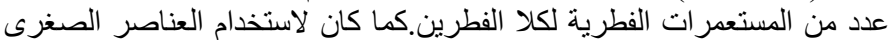

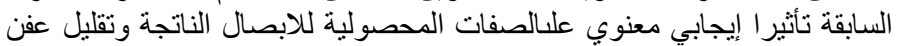

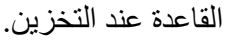

أدي الرش بالعناصر ألصغري لنباتات البصل إلي زئي زيادة نشاط أنزيمات

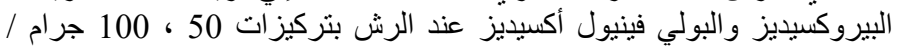

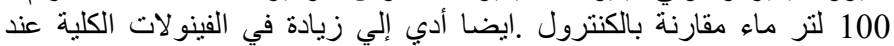

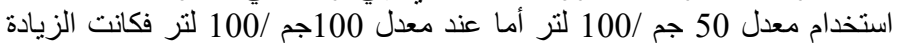

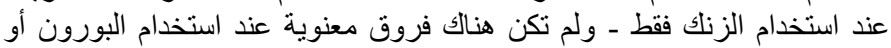

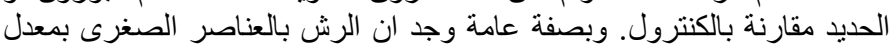

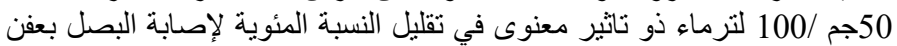

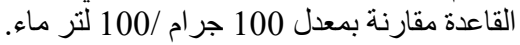

